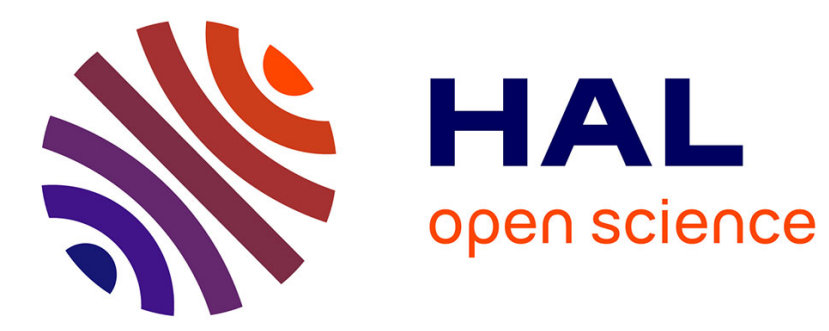

\title{
Immigrant fertility in West Germany: Is there a socialization effect in transitions to second and third births?
}

Nadja Milewski

\section{- To cite this version:}

Nadja Milewski. Immigrant fertility in West Germany: Is there a socialization effect in transitions to second and third births?. European Journal of Population / Revue européenne de Démographie, 2010, 26 (3), pp.297-323. 10.1007/s10680-010-9211-0 . hal-00535485

\section{HAL Id: hal-00535485 \\ https://hal.science/hal-00535485}

Submitted on 11 Nov 2010

HAL is a multi-disciplinary open access archive for the deposit and dissemination of scientific research documents, whether they are published or not. The documents may come from teaching and research institutions in France or abroad, or from public or private research centers.
L'archive ouverte pluridisciplinaire HAL, est destinée au dépôt et à la diffusion de documents scientifiques de niveau recherche, publiés ou non, émanant des établissements d'enseignement et de recherche français ou étrangers, des laboratoires publics ou privés. 


\title{
Immigrant fertility in West Germany: Is there a socialization effect in transitions to second and third births?
}

\section{Fécondité des immigrées en Allemagne de l'Ouest: existe-t-il un effet de la socialization dans le passage du premier au deuxieme enfant et dans celui du deuxieme au troisieme enfant?}

\section{Nadja Milewski}

Received: 3 February 2009/Accepted: 18 February 2010/Published online: 1 April 2010

(C) Springer Science+Business Media B.V. 2010

\begin{abstract}
In this paper on immigrant fertility in West Germany, we estimate the transition rates to second and third births, using intensity-regression models. The data come from the German Socio-Economic Panel Study. We distinguish women of the first and the second immigrant generations originating from Turkey, the former Yugoslavia, Greece, Italy, and Spain, and compare their fertility levels to those of West German women. In the theoretical framework, we discuss competing hypotheses on migrant fertility. The findings support mainly the socialization hypothesis: the transition rates of first-generation immigrants vary by country of origin, and the fertility patterns of migrant descendants resemble more closely those of West Germans than those of the first immigrant generation. In addition, the analyses show that fertility differentials between immigrants and women of the indigenous population can largely, though not in full, be explained by compositional differences.
\end{abstract}

Keywords Birth transitions - Life-course analysis · Migrant workers · Germany · Intensity-regression model

Résumé Dans cet article relatif à la fécondité des immigrées en Allemagne, le passage du premier au deuxieme enfant et dans celui du deuxieme au troisieme enfant est estimé à partir de modèles de régression à risques instantanés. Les données utilisées proviennent de l'étude de Panel socio-économique allemand. On distingue les femmes immigrées de première ou de seconde génération originaires de Turquie, d'ex-Yougoslavie, de Grèce, d'Italie et d'Espagne, et leurs niveaux de fécondité sont comparés à ceux des femmes ouest-allemandes d'origine. Des hypothèses concurrentes sur la fécondité des immigrés sont discutées dans le cadre

\footnotetext{
N. Milewski ( $\square)$

Institute for Sociology and Demography, University of Rostock,

Ulmenstr. 69, 18057 Rostock, Germany

e-mail: nadja.milewski@uni-rostock.de
} 
théorique. Les résultats vérifient principalement l'hypothèse de la socialisation : le passage au deuxieme et au troisieme enfant de la première génération d'immigrés varie selon le pays d'origine, et le profil de fécondité par âge des descendantes d'immigrées se rapproche plus de celui des femmes ouest-allemandes que de celui des immigrées de première génération. De plus, les analyses montrent que les différences de fécondité entre les immigrées et les femmes ouest-allemandes peuvent être en grande partie, mais pas totalement, expliquées par des différences de structure.

Mots-clés Passage au deuxieme et au troisieme enfant .

Analyse de parcours de vie · Travailleurs migrants · Allemagne ·

Modèles de régression à risques instantanés

\section{Introduction}

International migration is associated with a rapid change in people's environment and affects their subsequent demographic behavior. As Western Europe has been faced with growing immigration flows since the middle of the 20th century and the numbers of descendants of international migrants living today in Western European destination countries are rising, attention has also to be paid to immigrant family dynamics and fertility. Research on the interplay between international migration and fertility is especially interesting in order to draw conclusions about the development of immigrant sub-populations in the respective destination countries.

In general, studies on fertility of international migrants center on five, partly competing hypotheses which mainly focus on the first generation of migrants. Given fertility differentials between country of origin and country of destination, two outcomes may be hypothesized for the fertility of international migrants: immigrants may have a higher fertility or a lower fertility than women of the population at destination (including a convergence with the fertility levels of persons at destination). Explanations for a fertility stipulating effect are offered by the hypothesis on the interrelation of events and the socialization hypothesis. An effect of decreasing fertility, in contrast, may be traced back to a disruptive impact of migration (the disruption hypothesis), or to adaptive processes (the adaptation hypothesis). Moreover, the selection and composition of the immigrant population can play a role (the hypothesis of selection and characteristics).

This study aims at contributing to the theoretical framework of impacts of migration on the subsequent fertility of immigrants and their descendants, compared with that of citizens of the country of destination, who have no immigration background. We employ the life-course approach (e.g., Mulder 1993; Mulder and Wagner 1993) that allows us to analyze the sequencing of several events, and therefore to study the short-term as well as the long-term effects of migration on a person's life. Germany has been Europe's main destination country until recently and serves as a good case study to broaden our general understanding of population behavior and changes in Western Europe, since labor migration to West Germany parallels trends in other Western European countries. 
We investigate the transitions to second and third births and our two main research questions are: Do immigrants continue to display the behavior of their old environment or do they adopt the behavior of the new environment? Does the fertility pattern of second-generation immigrants resemble that of their parents or that of West Germans? We pay attention to the role of socialization and the composition of sub-populations. We compare first and second generations of traditional labor-migrant women from Turkey, the former Yugoslavia, Greece, Italy, and Spain to West German women.

This article begins by introducing the theoretical considerations behind our analysis and then provides information on the West German context. This is followed by an introduction of the working hypotheses guiding this study as well as of the data, methods, and explanatory variables used. The analysis applies intensityregression techniques to the transition to second and third births using retrospective event-history data from the German Socio-Economic Panel Study. The results are discussed in the last section.

\section{Background}

\subsection{Theoretical Considerations}

Five hypotheses are discussed when studying the fertility behavior of international or internal migrants. They refer to timing effects, the socio-demographic characteristics of migrants and their descendants, as well as their living circumstances and cultural factors.

The underlying assumption of the disruption hypothesis is that a move in itself, as well as the time preceding and following the move, is stressful for a person; therefore, fertility is expected to be low shortly after the move. Evidence for the disruption hypothesis has been found for immigrants moving to Australia (Carlson 1985; Abbasi-Shavazi and McDonald 2000; Abbasi-Shavazi and McDonald 2002), Mexicans moving to the U.S. (Bean and Swicegood 1985; Stephen and Bean 1992), and immigrants to Canada (Ram and George 1990; Ng and Nault 1997). Studies on immigrants in Western Europe, however, do not find evidence for a fertilitydisruption effect of international migration (Andersson 2004 for Sweden; Milewski 2007 for Germany).

The hypothesis of interrelation of events draws on a confluence of events and assumes that immigration and union formation/marriage are interrelated. Therefore, fertility may increase after immigration, not due to the move, but due to household formation. Hence, fertility is expected to be high shortly after arrival (Mulder and Wagner 1993; Singley and Landale 1998). Evidence for this hypothesis has been found for international migrants, as well as for internal migrants, and in particular for the first child (Lindstrom 2003; Andersson 2004; Kulu 2005; Kulu 2006; Milewski 2007; Nedoluzhko and Andersson 2007). For higher order births, this hypothesis has hardly been tested. Ram and George (1990), however, find increasing birth numbers after arrival in Canada and assume that immigrants have a desire to have additional children in the new home country. 
While the hypotheses of disruption and interrelation of events focus on shortterm impacts of migration, the adaptation hypothesis offers a medium-term perspective. Given that fertility patterns vary between the regions of origin and destination, a convergence may be achieved within some years of residency (shown by Iutaka et al. 1971; Rindfuss 1976; Bach 1981; Farber and Lee 1984; Hervitz 1985; Nauck 1987; Ford 1990; Ram and George 1990; Schoorl 1995; Mayer and Riphahn 2000; Milewski 2007). This resemblance may be triggered by two primary channels: cultural factors and/or socio-economic conditions.

An alternative is offered by the socialization hypothesis. This hypothesis emphasizes the role of the migrants' socialization by focusing on the values, norms, and behavior dominant during a person's childhood, and assumes their continuance during the life course. Accordingly, immigrants may follow a fertility pattern of their country of origin, even if it differs from that of the host society. Immigrants from different countries of origin that exhibit different fertility patterns may show the same fertility differences in the country of destination. This has been proven for immigrants in several Western European countries (Schoorl 1990; Alders 2000; Andersson 2004; Andersson and Scott 2007; Sobotka 2008), as well as for several origin groups to the U.S. (Massey 1981; Kahn 1988) and internal migrants (Hervitz 1985).

The long-term impact of migration can be observed in the fertility behavior of immigrant descendants, who are exposed to their parents' behavior, values, and norms, as well as to those prevailing in the receiving country. If the societal environment during childhood and adolescence was dominant in a meaning-giving system, the women of the second immigrant generation, who were born to immigrant parents in the new destination, would consequently display behavior typical at destination, i.e., behavior that differs from that of their parents. This is also known as the assimilation hypothesis in the U.S. context. Whereas in the past, these generational differences have been seen as a continuous process (Gordon 1964; Kahn 1988; Stephen and Bean 1992), more recent research allows for a more diversified picture. Portes and Zhou (1993) point out that a process of adaptation should be seen as segmented or selective assimilation.

Earlier studies have not found a common pattern for the fertility behavior of immigrant-descent groups at several destinations in traditional immigrant countries, and it has been demonstrated that the various groups at the same destination do not follow a similar pattern (Kahn 1994). Fertility levels of second-generation immigrants are, in the main, between those of the first immigrant generation, and the birth rates of the women of the majority population at destination (Kahn 1988 for the U.S.; Stephen and Bean 1992 for Mexican-origin women in the U.S.; Landale and Hauan 1996 for Puerto Ricans to the U.S.; Abbasi-Shavazi and McDonald 2000 and Khoo et al. 2002 for Australia). Abbasi-Shavazi and McDonald (2002) find, however, in another study that the fertility levels of second-generation Australians closely resembled the levels, trends, and age patterns of the respective countries of origin. Therefore, they argue for the importance of 'cultural maintenance' (Abbasi-Shavazi and McDonald 2002, p. 70).

Previous studies on Western European destination countries have produced contrasting findings that indicate a need to better understand the effects of 
international migration on subsequent fertility. Differences between findings in Northern America and Western Europe are striking and enhance the debate on modes of immigrant incorporation in the 'New' and 'Old world' (c.f. Kulu and Milewski 2007). For the still relatively young second immigrant generation in Western European countries, a non-uniform picture is seen: Alders (2000) notes that in the Netherlands fertility levels of women of Turkish and Moroccan parents fall between the levels of their mothers' generation and that of Dutch women, whereas women from Suriname and the Antilles exhibit lower levels than Dutch women. In Belgium, Schoenmaeckers et al. (1998) observe differences in fertility patterns of women of Turkish and Moroccan descent, including lower fertility levels for the second generation of both groups compared to the first generation. Milewski (2007) and Garssen and Nicolaas (2008) find fertility levels close to convergence with that of the majority population in Germany and The Netherlands, respectively. When comparing the fertility measures of women of the same origin group at different destinations in Western Europe, it seems that the receiving context shapes reproductive behavior to a large extent; however, a systematic study is still missing.

According to the hypothesis of selection and characteristics, similarities or differences in fertility behavior between immigrants and persons of the country of destination may be traced back to the selectivity of the migrant groups concerning their fertility intentions, which may be more similar to those prevalent in the destination country than to those characteristic of the country of origin. However, immigration may favor certain socio-demographic groups that are amenable to having more children than is typical among the population of the country of destination (or even among the population at origin). Fertility differentials may therefore be explained by compositional differences, and may vanish as the sociodemographic structure of an immigrant group grows to resemble that of the indigenous population at destination. Following this hypothesis, first-generation immigrants are assumed to share the fertility intentions of the persons at destination and to display a similar reproductive behavior. The selection can result from unobserved factors, such as social-mobility ambitions or family proneness, or from observed characteristics, such as education triggering migration (Macisco et al. 1969; Macisco et al. 1970; Zarate and Unger de Zarate 1975; Hiday 1978; Sabagh and Yim 1980; Bach 1981; Massey 1981; Kahn 1988; Schoorl 1990; Wagner 1990; Goldstein, White, and Goldstein 1997; Hwang and Saenz 1997; Frank and Heuveline 2005; Kulu 2005). Most studies that control for socio-demographic characteristics find fewer fertility differentials between first-generation-migrant groups and the indigenous population. Evidence for this hypothesis has also been found in nearly all studies on fertility of migrant descendants (Goldscheider and Uhlenberg 1969; Sly 1970; Roberts and Lee 1974; Bean and Marcum 1978; Bean and Tienda 1990; Schoorl 1990; Frank and Heuveline 2005; Poston, Chang, and Dan 2006; Milewski 2007).

\subsection{The West German Context}

Following the Second World War, West Germany became Western Europe's main destination country for migrants from Eastern Europe (ethnic minorities), labor 
migrants, as well as refugees and asylum seekers. Today, Germany has about 82 million inhabitants, of which around $10 \%$ are of foreign nationality. A total of 1.4 million were born to immigrants residing in Germany. The focus of our analysis is on women originating from countries that have provided West Germany with labor migrants since the 1950s. West Germany started recruitment activities in Southern Europe as early as the beginning of the Wirtschaftswunder. Its first 'guest-worker' treaty was signed with Italy in 1955. Treaties followed with Spain in 1960, Greece in 1960, Turkey in 1961, Morocco in 1963, Portugal in 1964, Tunisia in 1965, and Yugoslavia in 1968. Whereas in 1960, half of the migrant workers came from Italy, 4 years later Greece and Spain had taken over. Then Turkey dominated from the end of the 1960s until 1973, when a recruitment ban was put into force. Since then immigration has been dominated by family-related moves (Münz and Ulrich 2000; Rudolph 2002).

Comparing the immigrant populations in West Germany with Germans shows that their socio-demographic structure is still characterized by the former 'guestworker' milieu. Such a downward-trend of international migrants has been also observed in other countries of destination (Fassmann 1997; Bender and Seifert 2000; Constant and Massey 2005). This includes educational attainment, in the sense that the educational qualifications of immigrants are on average lower than that of native-born persons, or immigrants cannot utilize their education to the fullest in the labor market. This disadvantage also continues to their children's generation. Yet, a general trend towards higher education has become visible among younger cohorts in the last years (Seifert 1997; Fritzsche 2000; Konietzka and Seibert 2003).

As the duration of stay of foreign workers in West Germany increases and their descendants reach childbearing ages, immigrant fertility is receiving more attention. In the 1960 s, only about $5 \%$ of newborn children in Germany were of non-German nationality. By the end of the previous century, about 100,000 newborn babies per year, roughly $13 \%$ of all births, were of foreign nationality. The peak was reached in 1974 with $17 \%$. Whereas the total fertility rate (TFR) of West German women has been relatively stable since the 1970s (about 1.3), the fertility of immigrant women from Mediterranean countries has declined over the past three decades. This decline in the TFR of foreigners after 1975 was not equally distributed among nationalities. The decrease first set in for married couples from Spain, followed by Yugoslavian, Italian, and Greek couples 1 year later. The largest decline of the TFR was later registered in Turkish couples; however, their TFR still remained above that of Germans and other immigrant groups and today it is even higher than the TFR of persons who live in Turkey (Münscher 1979; Vaskovics 1987; Schwarz 1996; Roloff 1997; BMFSFJ 2000; Yavuz 2008). Due to several causes of a systematic underestimation, Germany's Federal Statistical Office has discontinued the calculation of immigrant-fertility figures (c.f. Nauck 2007).

While the fertility of immigrants to West Germany declined, birth rates fell in the respective countries of origin of the labor migrants as well. Compared to the 1970s, the TFR had decreased by about one child on average: in Greece to 1.4, in Italy to 1.3, in Spain to 1.2, and in Turkey to 2.8 by the mid-1990s (BMFSFJ 2000). 
As far as the fertility behavior of immigrants in Germany is concerned, only few studies employ the life-course approach. A study on the transition to a first birth (Milewski 2007) indicates that second-generation immigrants are more adapted to the lower fertility levels of West Germans than is their mothers' generation. For first-generation immigrants, first-birth risks show hardly any differences by country of origin, however. The latter result is attributed to the universality of marriage in the respective countries of origin and to a selection of immigrants by family-reunion processes. Since fertility differentials in the respective countries of origin appear mainly in the parities 2 and higher (Shorter and Macura 1982; Delgado Perez and Livi-Bacci 1992; Hancioglu and Ergöcmen 2004), the study of subsequent-birth behavior will allow us to draw conclusions on the impact of socialization on fertility.

\subsection{Working Hypotheses}

(H1) Disruption-first-generation immigrants: Assuming that a move abroad constitutes a stressful situation in life, it is logical to conclude that the stress associated with an international move will be even greater when a woman migrates with one or two children. A mother and a child are at least two people having to cope with the changes, and this number increases with a partner or additional children. Therefore, it can be hypothesized that those women of the first immigrant generation who moved to West Germany when they already had one or two children will have lower transition rates to a second or third birth than women without any, or without recent, migration experience.

(H2) Interrelation of events-first-generation immigrants: The second hypothesis contradicts the disruption argument and posits higher birth rates. Even though a (subsequent) marriage may be an exceptional case for one- or two-child mothers moving to West Germany, it can be assumed that several events appear within a short time frame: the reunion of the spouses and the family. Since it was typical for the 'guest-worker' immigration that the partners moved at different points in time, their reunion can be seen as a formation of a new household or as a re-formation of an old household under new circumstances. This re-formation and the migration of the woman and the first one or two children occur simultaneously, and may trigger an effect of 'union or family confirmation.' This could also be seen as a time to catch-up with births which were postponed in anticipation of the move.

(H3) Adaptation-first-generation immigrants: Our hypothesis is that the fertility levels of first-generation immigrants converge towards the levels of West Germans by increasing length of stay. Accordingly, we assume to find fertility differentials between immigrant women who have stayed longer in Germany and those who have newly arrived.

(H4) Socialization-first-generation immigrants: We expect to find fertility differences by country-of-origin group. Whereas a first child has been almost universal in the respective countries of origin until recently, the frequencies of second and third children are different. If socialization has an influence on fertility 
behavior, higher transition rates to a second and a third child are expected for women of the first immigrant generation from Turkey than for women from the former Yugoslavia, Greece, Italy, and Spain.

Second-generation immigrants: Immigrant descendants may show birth risks which are similar to those of West Germans, but are different (i.e., lower) from those of the first immigrant generation. For second-generation immigrants, it is assumed that the West German context is more dominant than the country background of their parents, and that the fertility behavior of the second generation does therefore not vary between the different country groups.

(H5) Characteristics-first- and second-generation immigrants: Finally, we review the assumption of characteristics and selection. We assume that fertility differentials between immigrants and West Germans as well as between the immigrant generations-if they exist-will be diminished or extinct when controlling for socio-demographic characteristics of the respective groups.

\subsection{Data, Covariates, and Method}

\subsubsection{Data}

The data used in this study come from the German Socio-Economic Panel (GSOEP; DIW 2006; Haisken-DeNew and Frick 2003). Respondents have been questioned annually since 1984 and our study uses data from the waves 1984 to 2004. The GSOEP also provides retrospective background information, such as on childbearing, marriage, immigration, and education.

The focus of our study is on women who were born between 1946 and 1983 and who lived in West Germany at any time of the survey. ${ }^{1}$ Women in our analysis are considered to be West Germans if they were born in Germany and reported German nationality in each survey year. Women are classified as immigrants or as having an immigration background if they ever reported having a non-German nationality, and/or if they were born abroad (even if a change of citizenship took place later). All respondents of the sub-samples A, B, and D who can be defined as being of Turkish, former Yugoslavian (or its successor states in the sample: Croatia, BosniaHerzegovina, Macedonia, Slovenia), Greek, Italian, Spanish, or West German origin were included in our analysis.

The distinction between the immigrant generations is relatively broad in this analysis: Age 15 is chosen as a cutoff point for distinguishing between the immigrant generations: immigrants coming to Germany at age 15 and older are considered to be of the first immigrant generation; while women migrating under

\footnotetext{
1 The foreign population is not evenly distributed in Germany (Destatis 2005). Still among all foreigners, only about four percent live in the eastern federal states and East Berlin. Therefore, our analysis is on women living in the western part of Germany.
} 
age 15 , or who were born in Germany to at least one immigrant parent, are defined as second-generation migrants (c.f. Abbasi-Shavazi and McDonald 2002). The main reason for using age 15 to distinguish between the immigrant generations is that compulsory school education in Germany generally ends at about age 15 or 16. Hence, persons immigrating at younger ages are assumed to participate in school education in Germany, and are therefore more exposed to the influence of German socialization than older immigrants, who no longer participate in compulsory education. Further distinctions within the second-generation group are not feasible as the GSOEP data do not always contain such information such as whether both of the respondent's parents are immigrants. Therefore, the group defined as secondgeneration migrants includes persons who have both one and two immigrant parents. No distinction is made between the second-generation migrants born in Germany (generation 2) and those who moved during childhood (generation 1.5), (c.f. Rumbaut 2004). This choice is related to the small size of the sample. (However, a preliminary analysis which distinguished between the generations 1.5 and 2 revealed no significant differences.) Thus, not all of these persons are 'real' immigrants in the sense that they migrated themselves and decided to do so on their own. The term 'second-generation (im)migrants' is used here in order to identify any migration background whatsoever.

In total, valid biographic information was gathered and birth histories constructed for 5,483 women. Of these, 728 are first-generation immigrants, 828 are secondgeneration migrants, and 3,932 are non-immigrant West German women.

We analyze second- and third-child fertility separately and take into account only the fertility behavior after immigration. Hence, first-generation immigrants who had given birth to two or more children before they moved from their home countries cannot be considered for the respective transitions in West Germany at all. Cases where a birth took place in the same year as the immigration were excluded as well because these pregnancies may be correlated with the anticipation of the move.

The focus of the analysis is on those women who are in a first marriage. We do not expect that the exclusion of women living in non-marital cohabitation will bias the results as there were so few immigrant women cohabitating in our sample. In total, less than $6 \%$ of first-generation immigrants were not married at the time of censoring. Among the first-generation immigrant women in our sample who had already had one child, there were no unmarried mothers, and only $1 \%$ of the mothers of the second migrant generation were not married, compared to $3.4 \%$ of West German mothers. A record is censored at the end of the first marriage (the periods of time a woman may have spent in a subsequent marriage are excluded from the analysis).

After the respective cases as described above were excluded, two different subsamples are used for the respective birth transitions. The sub-sample for the secondchild transition contains 454 first-generation immigrants, including 407 who gave birth to their first child in West Germany and 47 who arrived with one child. This sub-sample includes 287 second-generation migrants and 1771 West Germans. The third-child sample includes 415 first-generation immigrants, 172 second-generation migrants and 1099 West Germans (see Table 1). 
Table 1 Overview of the sub-samples used

\begin{tabular}{|c|c|c|c|c|c|}
\hline & \multirow[t]{2}{*}{ Initial sample } & \multicolumn{2}{|c|}{ Second child } & \multicolumn{2}{|c|}{ Third child } \\
\hline & & Persons & Events & Persons & Events \\
\hline First-generation immigrants & 782 & 454 & 361 & 415 & 174 \\
\hline Second-generation immigrants & 828 & 287 & 177 & 172 & 57 \\
\hline West Germans & 3,932 & 1,771 & 1,122 & 1,099 & 283 \\
\hline
\end{tabular}

Source: Calculations based on GSOEP, 1984-2004

Note: Events: conceptions (counted as 9 months before recorded birth). Differences between person numbers in sub-sample 3 and events in second-birth numbers are due to missing information; exclusion of twin births as well as divorced women; inclusion of immigrants moving during pregnancy or with children

\subsubsection{Covariates}

The covariates capturing migrant-specific characteristics are immigrant generation and country of origin (for immigrants derived from ever-reported non-German citizenship).

The school degree of the woman is used as an indicator of the socio-economic background. Several school-degree categories are constructed. 'First degree' designates completion of Hauptschule (9 years of schooling) or Realschule (10 years of schooling) in Germany, or of the completed level of compulsory school education in the respective country of origin. 'Second degree' refers to completion of the German Abitur or Fachabitur, or the equivalent secondary education abroad (a certificate qualifying for entry into college or university). The third category captures respondents who did not receive any school degree or have never attended school. We decided to focus on school-leaving certificates instead of tertiary education (university) because this is more appropriate to the sample. The firstgeneration immigrants had left school before their move. About $28 \%$ of the firstgeneration immigrants in the second-birth sub-sample did not complete school with any degree, compared to about $20 \%$ of the women of the second generation (about $1 \%$ among West Germans). Only roughly $13 \%$ of the women of the first immigrant generation and $7 \%$ of the second generation completed secondary school education (compared to $17 \%$ among West Germans). The differences in educational attainment may cause differences in fertility levels. Mainly (and in contrast to first-child behavior) we assume that higher education increases childbearing intensities [Kreyenfeld (2002) on parity 2; Kravdal (2007)] on parities 2 and 3).

It is possible to identify the partner(s) of each woman during the panel time because the GSOEP contains information on the household to which she belongs since 1983. Hence, our procedure was as follows: a woman married only once is related for the whole duration of the marriage (i.e., also before 1983) to the partner she was sharing a household with during the time of the panel. In contrast, a woman who was separated, divorced, or widowed before the time of the panel (i.e., before 1983) cannot be linked to her first partner or spouse (i.e., the covariates capturing information on the spouse have missing values). If information on the spouse was 
available, the partner's educational attainment was included in the analysis. The share of husbands without school degree is highest among the first immigrant generation (15\%, compared to 7 and less than $1 \%$ among the second generation and West Germans, respectively), whereby $16 \%$ of the partners of first-generation immigrants hold a secondary degree (20 and 23\% in the second generation and among West Germans, respectively).

In the second-child analysis, the indicator of the age of the mother at the first birth is used: 'younger than 20 years,' '20-24 years,' '25-29 years,' '30-34 years,' and ' $35+$ years.' In the analysis of child 3, the age of the mother at the previous birth refers to parity 2. Since the first-birth behavior of immigrant women in West Germany is characterized by a relatively early start (Milewski 2007), the migrants' transition rates to a higher parity may be elevated compared to West Germans.

Moreover, the analysis controls for birth cohort. The categories of this variable are as follows: '1946-1959,' '1960-1969,' and '1970+.' They are based on the phases of labor immigration to West Germany and the developments in fertility rates in West Germany, mainly the baby boom in the 1960s and its end at the beginning of the 1970s. In a preliminary analysis, an indicator for the immigration cohort of first-generation immigrants was used. The estimates showed higher birth risks for first-generation immigrants who had moved since 1980 than for women who immigrated between the 1960s and 1980, thus indicating a shift from familyreunion moves towards marriage migration. Because of the relatively small sample size, we decided to include the birth cohort (and not the immigration cohort) since it applies to all women in the sample.

For sample statistics, see Tables 2 and 3. Note that missing values appear as 'n.a.' in the tables; this represents both 'no answer' and 'not applicable' (as in the case of immigrant-specific covariates).

The GSOEP contains many more variables that would be of interest for the research question of our study. It may, for example, be possible to imagine indicators for whether an immigrant woman had ever been gainfully employed in her life, or whether she has a command of the German language. However, the variables under consideration would have caused problems for our analysis. Either the respective question was asked only of one of the sub-groups, or the response rates turned out to be too low for the sample drawn. Another problem is that some of the variables of possible interest were not asked in each survey year and that socioeconomic information, such as on employment and income, were asked only in the panel time (i.e., from 1983 on). Since the respective covariate may have changed over time, it is not possible to correctly estimate its impact on childbearing (anticipatory analysis, c.f. Hoem and Kreyenfeld 2006); and some of the variables simply had too many missing values.

\subsubsection{Method}

This study analyzes the transitions to a second and third conception leading to a live birth. Piecewise-linear intensity regression models are estimated as a form of indirect standardization, as suggested by Hoem (1987; c.f. Hoem 1993; Blossfeld and Rohwer 1995; Andersson 2004). Monthly information on births, available for 
Table 2 Sample statistics: transition to a second child-person-months (exposures) and conceptions (occurrences)

\begin{tabular}{|c|c|c|c|c|c|c|c|c|c|}
\hline \multirow[t]{2}{*}{ Variable } & \multicolumn{3}{|c|}{$\begin{array}{l}\text { First-generation } \\
\text { immigrants }\end{array}$} & \multicolumn{3}{|c|}{$\begin{array}{l}\text { Second-generation } \\
\text { immigrants }\end{array}$} & \multicolumn{3}{|c|}{ West Germans } \\
\hline & Exposures & $\begin{array}{l}\text { Exp. } \\
\text { in } \%\end{array}$ & Occ. & Exposures & $\begin{array}{l}\text { Exp. } \\
\text { in } \%\end{array}$ & Occ. & Exposures & $\begin{array}{l}\text { Exp. } \\
\text { in } \%\end{array}$ & Occ. \\
\hline Total & 22,111 & & 361 & 12,331 & & 177 & 10,1130 & & 1,122 \\
\hline First birth in Germany & 20,362 & 92.1 & 321 & n.a. & & & n.a. & & \\
\hline $\begin{array}{l}\text { Move after first birth } \\
\text { abroad }\end{array}$ & 1,749 & 7.9 & 40 & n.a. & & & n.a. & & \\
\hline \multicolumn{10}{|l|}{ Women's characteristics } \\
\hline \multicolumn{10}{|l|}{ Country of origin } \\
\hline Turkey & 7,932 & 35.9 & 156 & 5,639 & 45.7 & 80 & & & \\
\hline Yugoslavia & 6,203 & 28.1 & 86 & 1,198 & 9.7 & 13 & & & \\
\hline Greece & 1,809 & 8.2 & 35 & 1,502 & 12.2 & 20 & & & \\
\hline Italy & 4,060 & 18.4 & 60 & 2,888 & 23.4 & 45 & & & \\
\hline Spain & 2,108 & 9.5 & 24 & 1,104 & 9.0 & 19 & & & \\
\hline \multicolumn{10}{|l|}{ Birth cohort } \\
\hline 1946-1959 & 14,547 & 65.8 & 237 & 2143 & 17.4 & 35 & 63,271 & 62.6 & 615 \\
\hline 1960-1969 & 4,842 & 21.9 & 83 & 7304 & 59.2 & 100 & 31,741 & 31.4 & 408 \\
\hline $1970+$ & 2,723 & 12.3 & 41 & 2884 & 23.4 & 42 & 6118 & 6.0 & 99 \\
\hline \multicolumn{10}{|l|}{ School education } \\
\hline No degree & 5,579 & 25.2 & 107 & 2753 & 22.3 & 36 & 694 & 0.7 & 12 \\
\hline First or other degree & 13,240 & 59.9 & 200 & 8605 & 69.8 & 129 & 86,762 & 85.8 & 919 \\
\hline Second degree & 2735 & 12.4 & 46 & 812 & 6.6 & 8 & 13,251 & 13.1 & 185 \\
\hline n.a. & 557 & 3.4 & 8 & 161 & 1.3 & 4 & 423 & 0.4 & 6 \\
\hline \multicolumn{10}{|l|}{ Age at first birth in years } \\
\hline$<20$ & 4,090 & 18.5 & 90 & 2,268 & 18.4 & 46 & 12,059 & 11.9 & 142 \\
\hline $20-24$ & 12,159 & 55.0 & 206 & 6,198 & 50.3 & 90 & 37,222 & 36.8 & 429 \\
\hline $25-29$ & 4,025 & 18.2 & 59 & 3,199 & 25.9 & 36 & 37,260 & 36.8 & 415 \\
\hline $30-34$ & 1,561 & 7.1 & 4 & 631 & 5.1 & 4 & 11,104 & 11.0 & 127 \\
\hline $35+$ & 276 & 1.2 & 2 & 35 & 0.3 & 1 & 3485 & 3.4 & 9 \\
\hline \multicolumn{10}{|l|}{ Spouse's characteristics } \\
\hline \multicolumn{10}{|c|}{ Spouse's school education } \\
\hline No degree & 3,477 & 15.7 & 58 & 749 & 6.1 & 16 & 776 & 0.8 & 6 \\
\hline First or other degree & 13,206 & 59.7 & 223 & 8,410 & 68.2 & 122 & 63,058 & 62.4 & 661 \\
\hline Second degree & 3,635 & 16.4 & 59 & 2,085 & 16.9 & 32 & 18,683 & 18.5 & 269 \\
\hline n.a. & 1,794 & 8.1 & 21 & 1,087 & 8.8 & 7 & 18,613 & 18.4 & 186 \\
\hline
\end{tabular}

Source: Calculations based on GSOEP, 1984-2004; event: second conception

births since January 1983, is used. For births occurring before 1983, only yearly data is available. As usual in demography, we impute such births to have occurred in June. In order to calculate the time at the corresponding conception, we count back nine months from the birth. 
Table 3 Sample statistics: transition to a third child-person-months (exposures) and conceptions (occurrences)

\begin{tabular}{|c|c|c|c|c|c|c|c|c|c|}
\hline \multirow[t]{2}{*}{ Variable } & \multicolumn{3}{|c|}{$\begin{array}{l}\text { First-generation } \\
\text { immigrants }\end{array}$} & \multicolumn{3}{|c|}{$\begin{array}{l}\text { Second-generation } \\
\text { immigrants }\end{array}$} & \multicolumn{3}{|c|}{ West Germans } \\
\hline & Exposures & $\begin{array}{l}\text { Exp. } \\
\text { in \% }\end{array}$ & Occ. & Exposures & $\begin{array}{l}\text { Exp. } \\
\text { in \% }\end{array}$ & Occ. & Exposures & $\begin{array}{l}\text { Exp. } \\
\text { in \% }\end{array}$ & Occ \\
\hline Total & 41,947 & & 174 & 11,328 & & 57 & 11,1421 & & 283 \\
\hline $\begin{array}{l}\text { Second birth in Germany } \\
\text { (total) }\end{array}$ & 36,153 & 86.2 & 149 & & & & & & \\
\hline First birth in Germany & 31,661 & 75.5 & 131 & & & & & & \\
\hline Move after first birth & 4,493 & 10.7 & 18 & & & & & & \\
\hline $\begin{array}{l}\text { Move after second birth } \\
\text { abroad }\end{array}$ & 5,790 & 13.8 & 24 & & & & & & \\
\hline \multicolumn{10}{|l|}{ Women's characteristics } \\
\hline Country of origin & & & & & & & n.a. & & \\
\hline Turkey & 11,901 & 28.4 & 100 & 3,867 & 34.1 & 30 & & & \\
\hline Yugoslavia & 15,180 & 36.2 & 25 & 798 & 7.0 & 6 & & & \\
\hline Greece & 5,276 & 12.6 & 15 & 1,801 & 15.9 & 4 & & & \\
\hline Italy & 6,647 & 15.8 & 27 & 3,163 & 27.9 & 13 & & & \\
\hline Spain & 2,943 & 7.0 & 7 & 1,700 & 15.0 & 4 & & & \\
\hline \multicolumn{10}{|l|}{ Birth cohort } \\
\hline 1946-1959 & 34,323 & 81.8 & 123 & 3773 & 33.3 & 11 & 83,944 & 75.3 & 168 \\
\hline 1960-1969 & 5,809 & 13.8 & 37 & 6024 & 53.2 & 33 & 24,748 & 22.2 & 99 \\
\hline $1970+$ & 1,815 & 4.3 & 14 & 1531 & 13.5 & 13 & 2,729 & 2.4 & 16 \\
\hline \multicolumn{10}{|l|}{ School education } \\
\hline No degree & 12,999 & 31.0 & 65 & 2499 & 22.1 & 11 & 729 & 0.7 & 6 \\
\hline First or other degree & 22,714 & 54.1 & 89 & 8419 & 74.3 & 42 & 97,066 & 87.1 & 231 \\
\hline Second degree & 4,985 & 11.9 & 14 & 371 & 3.3 & 2 & 13,322 & 12.0 & 45 \\
\hline n.a. & 1,250 & 3.0 & 6 & 39 & 0.3 & 2 & 304 & 0.3 & 1 \\
\hline \multicolumn{10}{|l|}{ Age at second birth in years } \\
\hline$<25$ & 18,506 & 44.1 & 105 & 5,250 & 46.3 & 40 & 28,984 & 26.0 & 105 \\
\hline $25-29$ & 17,375 & 41.4 & 59 & 4,361 & 38.5 & 17 & 51,551 & 46.3 & 113 \\
\hline $30+$ & 6,067 & 14.5 & 10 & 1,717 & 15.2 & 0 & 30,886 & 27.7 & 65 \\
\hline \multicolumn{10}{|l|}{ Spouse's characteristic } \\
\hline \multicolumn{10}{|l|}{ Spouse's school education } \\
\hline No degree & 5141 & 12.3 & 33 & 1,189 & 10.5 & 4 & 377 & 0.3 & 3 \\
\hline First or other degree & 28,553 & 68.1 & 104 & 8,001 & 70.6 & 37 & 72,338 & 64.9 & 158 \\
\hline Second degree & 5785 & 13.8 & 22 & 1,802 & 15.9 & 14 & 23,792 & 21.4 & 75 \\
\hline n.a. & 2469 & 5.9 & 15 & 336 & 3.0 & 2 & 14,915 & 13.4 & 47 \\
\hline
\end{tabular}

Source: Calculations based on GSOEP, 1984-2004; event: third conception 
The model can be formalized as follows:

$$
\ln \mu_{i}(t)=y(t)+\sum_{l} \alpha_{l} x_{i l}
$$

where $\mu_{\mathrm{i}}(t)$ denotes the hazard of a pregnancy leading to a live birth for individual $i$ at process time $t$ and $y(t)$ represents the baseline log-hazard. For the transition to a second conception, the process time is the number of months since the first birth (age of the first child). Correspondingly, the process time for the transition to a third conception is the number of months since the second birth. Note that first-generation immigrants contribute to the exposure only from the time of arrival in West Germany.

The end of the respective process time (censoring) is either at the conception of the next order, at a dissolution of the first marital union of the woman, or at the last interview when neither conception nor union dissolution are reported.

The term $x_{i l}$ denotes the effect of a time-constant covariate on the hazard.

\section{Results}

\subsection{Transition to a Second Birth}

\subsubsection{Model 1.1}

Our first step in the intensity-regression analysis is to compare the main groups under consideration, controlling for the age of the first child only (see Table 4). Whereas there are no significant differences in second-birth rates between secondgeneration immigrants and West Germans, first-generation immigrants have a $31 \%$ elevated second-birth risk compared to West Germans.

\subsubsection{Model 1.2}

We then divided the first-generation immigrants into several sub-groups, and replaced the time-constant risk by a time-varying estimate. For the first-generation immigrants who had their first births in Germany, a distinct duration pattern cannot be identified. Significantly elevated transition rates are observed only in the third year of stay in West Germany relative to West Germans (about 40\%). However, the sample of first-generation immigrants who arrived with one child in West Germany is too small for a separate analysis with a time-varying risk by stay duration (this step is not displayed here). Therefore, we distinguish between the women who had the first birth in Germany, and those who had their first child before the move (see Table 4). The results reveal high transition rates for the new immigrants: the risk of having a second child among immigrants who arrive after the first birth is almost twice as high as that of West Germans. Although the transition rates of firstgeneration immigrants who had the first birth in Germany are lower, the latter group still has a significant $26 \%$ higher second-birth risk than West Germans.

This result suggests a kind of 'arrival' effect for the new immigrants, i.e., those who moved after the first birth. It also implies that immigrants who had their first 
Table 4 Factors influencing the transition to a second child-relative risks

\begin{tabular}{|c|c|c|c|}
\hline Variable & Model 1.1 & Model 1.2 & Model 1.3 \\
\hline West German & 1 & 1 & 1 \\
\hline \multicolumn{4}{|l|}{ Immigrant generation } \\
\hline First generation (total) & $1.31 * * *$ & & \\
\hline First generation with first birth in Germany & & $1.26 * * *$ & $1.15^{*}$ \\
\hline First generation with first birth abroad & & $1.96^{* * *}$ & $1.70 * * *$ \\
\hline Second generation & 1.03 & 1.03 & 0.95 \\
\hline \multicolumn{4}{|l|}{ Age at first birth in years } \\
\hline$<20$ & & & 1 \\
\hline $20-24$ & & & 0.90 \\
\hline $25-29$ & & & $0.79 * * *$ \\
\hline $30+$ & & & $0.55 * * *$ \\
\hline \multicolumn{4}{|l|}{ Birth cohort } \\
\hline 1946-1959 & & & 1 \\
\hline 1960-69 & & & 1.02 \\
\hline $1970+$ & & & 0.94 \\
\hline \multicolumn{4}{|l|}{ School education } \\
\hline No degree & & & 1.13 \\
\hline First or other degree & & & 1 \\
\hline Second degree & & & $1.17 * *$ \\
\hline n.a. & & & 0.86 \\
\hline \multicolumn{4}{|l|}{ Spouse's school education } \\
\hline No degree & & & 0.97 \\
\hline First or other degree & & & 1 \\
\hline Second degree & & & $1.22 * * *$ \\
\hline n.a & & & $0.84 * *$ \\
\hline \multicolumn{4}{|l|}{ Age of first child in years (slope) } \\
\hline $0-2$ & $0.042 * * *$ & $0.042 * * *$ & $0.042^{* * *}$ \\
\hline $2-4$ & $-0.018 * * *$ & $-0.018 * * *$ & $-0.018 * * *$ \\
\hline $4-6$ & $-0.013 * *$ & $-0.013 * *$ & $-0.013 * *$ \\
\hline $6+$ & $-0.027 * * *$ & $-0.027 * * *$ & $-0.027 * * *$ \\
\hline Constant & $-4.808 * * *$ & $-4.801 * * *$ & $-4.637 * * *$ \\
\hline Log-likelihood & $-8,875$ & $-8,872$ & $-8,846$ \\
\hline
\end{tabular}

Source: Calculations based on GSOEP, 1984-2004, event: second conception

Note: Significance: * $10 \%, * * 5 \%, * * * 1 \%$

child already in Germany are more adapted to West German second-birth behavior than are the women who immigrated only after the first birth.

\subsubsection{Model 1.3}

We continue the modeling process by including characteristics of the women. Model 1.3 (Table 4) adds the age of the women at the first birth. About $80 \%$ of the 
first-generation immigrants in the sample had become mothers before age 25 , whereas this share is about $70 \%$ among the second generation, and is barely $50 \%$ among West Germans. Controlling for this covariate reduces the second-child risks of both first-generation sub-groups, but they remain elevated. The results show significantly lower transition rates for women who gave birth for the first time at age 25 or older than for women who became mothers at younger ages. In the same step, the indicator of the women's birth cohort is introduced; this covariate does not add any explanation to the model, though.

The next step adds the educational attainment of the women. The immigrant groups and West Germans differ significantly in terms of socio-demographic composition: while the share of women without a school-leaving certificate is higher among the first and second generations than among West Germans, the latter group has a higher share of women with secondary school education (see Sect. 2.4.2). Controlling for education reduces the differences in second-birth risks between the first generation whose first birth was in Germany and West Germans by about $6 \%$. There is also a diminishing effect for the women of the first immigrant generation who arrived with one child in West Germany, but the birth risk among this group remains quite elevated. The effect of the school-leaving certificate on second-birth risks is similar for the groups: women who completed secondary education have higher transition rates to a second child, compared to women without a school degree or with a first degree. This effect is the opposite of the impact of education on firstbirth behavior, whereby women with secondary education have lower transitions to motherhood. This finding is in accordance with the results of a study by Kreyenfeld (2002); Kravdal (2007) has demonstrated selection effects also for Norway.

We also used employment status in the modeling of the second-birth behavior since first-birth analyses have revealed that non-employment is of crucial importance both for the immigrant groups and West Germans, i.e., women have elevated birth risks during periods of non-employment (Hennig and Kohlmann 1999; Milewski 2007). The same is true for the transition to the second birth. The conception risk is higher for non-employed women than it is for women employed full-time. Unlike in the firstbirth analysis, however, the employment status cannot explain the fertility differentials between the first immigrant generation and West Germans. Since the sample is relatively small and the employment spells become less reliable especially in the thirdbirth transition, we have not included employment in the analyses presented here.

The educational level of the husband is also controlled for. The partner's higher education is associated with higher second-birth risks, which confirms other findings (Kreyenfeld 2002; Kravdal 2007).

Note that none of these steps changes the result that second-generation migrants and West Germans do not show any differences in second-birth risks.

\subsubsection{Model 1.4}

The final steps in our analysis take the immigration background of the women into account. Due to the small sample size, no distinction is made by country of origin for the new first-generation immigrants who arrived after the first birth. For the first generation with the first birth in Germany and the second generation, tests were 
Table 5 Factors influencing the transition to a second child: country of origin-relative risks

\begin{tabular}{lc}
\hline Variable & Model 1.4 \\
\hline West German & 1 \\
Immigrant generation and country of origin & $1.27 * *$ \\
First generation with first birth in Germany, Turkey & 1.08 \\
First generation with first birth in Germany, SSEE & $1.71^{* * *}$ \\
First generation with first birth abroad & 0.90 \\
Second generation, Turkey & 1.01 \\
Second generation, SSEE & $-8,845$ \\
Log-likelihood & \\
\hline
\end{tabular}

Source: Calculations based on GSOEP, 1984-2004, event: second conception

Note: Significance: $* 10, * * 5 \%$; $* * * 1 \%$; controlled for age of the first child, age at first birth, birth cohort, school education of the woman; school education of spouse

SSEE (Southern and Southeastern Europe): Yugoslavia, Greece, Italy, Spain

made by country of origin. The results are not shown here since they do not reveal any significant differences between the various countries. The only exception is the 'old' first-generation Turks whose second-birth risk is $27 \%$ higher than that of West Germans (see Table 5). Second-generation Turks, as well as first- und secondgeneration immigrants from the former Yugoslavia, Greece, Italy, and Spain, show no significant differences when compared to first-generation Turks or West Germans (results not shown here). Therefore, the country backgrounds of the four Southern and Southeastern European countries (SSEE) are combined.

In addition, we have tested the effect of further covariates (not displayed here). These variables are shown to affect immigrants and West Germans in a similar manner, but do not explain fertility differentials if existent after the control variables are added as described. For example, the variable on the type of the place where the woman lived at age 15 was, after several tests, categorized into rural versus urban. Results showed, in line with the literature (e.g., Kane 1986), that women with an urban background have significantly lower transition rates both to a first and to a second birth. The religious affiliation has one category with a significant effect on second births, i.e., having no religious affiliation was found to have a birth-risklowering impact (e.g., Mayer and Riphahn 2000). In general, this probably reflects more of the variability within the West German group than differences between immigrants and Germans; for immigrants there appears to be a relatively high association between country background and religion. Therefore, it may be more appropriate to focus on structural indicators than on cultural attributes.

\subsection{Transition to a Third Birth}

\subsubsection{Model 2.1}

The first modeling step in the third-birth analysis compares the immigrant generations to West Germans using the age of the second child as basic process 
time. Model 2.1 (see Table 6) applies the simple distinction between the first and second immigrant generations. In line with the analyses on the second births, firstgeneration immigrants have a significantly higher risk of having a third child than do West Germans $(+27 \%)$. The transition rates of women of the second generation appear to be elevated by almost the same magnitude, although the differences between the second generation and West Germans, as well as between the second and the first generations, are not significant.

\subsubsection{Model 2.2}

To explore whether it is possible to discern an effect of an interrelation of events for immigrants who arrived with two children, or an effect of adaptation or disruption among the first immigrant generation, we take into account the timing of the previous births and of the move in the next steps. Model 2.2 (Table 6) compares women who had their first and second children before moving to Germany to those who had their second child in Germany (with the first child having been born either before or after the move). As in the case of the transition to the second child, we find significantly increased birth risks for the new immigrants compared with the birth risks for West Germans. These women have a $77 \%$ higher transition to a subsequent child, whereas the risk of the earlier immigrants is only $20 \%$ higher (also significant).

\subsubsection{Model 2.3}

Model 2.3 controls for the age of the woman at the second birth (see Table 6). More than $40 \%$ of the women of both immigrant generations have had their second child before they turned 25, whereas this share is only about $20 \%$ among West Germans. Inserting this covariate reduces the significance of the difference in third-child risks between first-generation immigrants and West Germans, and it also reduces the third-birth risks by about a third. The effect of this variable are largely decreasing third-birth risks for the women who had their second birth at ages 25 to 29, and at ages $30+$.

This model also adds the birth cohort and school education of the women. The decrease in the birth risks of the immigrant groups (though group differences are not significant) indicates that compositional differences between the groups play a role in explaining fertility differentials: second-generation migrants are overrepresented in the birth cohorts $1960+$, and the third-birth risk for this group is around $40 \%$ higher than that of women born before 1960 .

As far as educational attainment is concerned, a U-shape effect is found. Women without a school-leaving certificate have an almost $40 \%$ higher risk of having a third child than do women with a first degree. With a share of about 30 and 20\%, respectively, first- and second-generation immigrants are far more frequently found in the category without a formal educational degree than West Germans. As in the analysis of the second child, having a higher level of education also increases the transition to a third child. This applies to both immigrant groups as well as to West Germans, and these results are in line with the findings by Kravdal (2007). 
Table 6 Factors influencing the transition to a third child-relative risks

\begin{tabular}{|c|c|c|c|}
\hline Variable & Model 2.1 & Model 2.2 & Model 2.3 \\
\hline West German & 1 & 1 & 1 \\
\hline \multicolumn{4}{|l|}{ Immigrant generation } \\
\hline First generation (total) & $1.27^{* * * *}$ & & \\
\hline First generation with second birth in Germany & & $1.20^{* *}$ & 1.11 \\
\hline First generation with second birth abroad & & $1.77 * * *$ & 1.12 \\
\hline Second generation & 1.24 & 1.23 & 1.02 \\
\hline \multicolumn{4}{|l|}{ Age at second birth } \\
\hline$<25$ years & & & 1 \\
\hline $25-29$ years & & & $0.60^{* * * *}$ \\
\hline $30+$ years & & & $0.44 * * *$ \\
\hline \multicolumn{4}{|l|}{ Birth cohort } \\
\hline 1946-1959 & & & 1 \\
\hline $1960-1969$ & & & $1.43^{* * *}$ \\
\hline $1970+$ & & & $1.86 * * *$ \\
\hline \multicolumn{4}{|l|}{ School education } \\
\hline No degree & & & $1.39 * *$ \\
\hline First or other degree & & & 1 \\
\hline Second degree & & & $1.26^{* *}$ \\
\hline n.a. & & & $1.85^{* *}$ \\
\hline \multicolumn{4}{|l|}{ Spouse's school education } \\
\hline No degree & & & $1.59 * * *$ \\
\hline First or other degree & & & 1 \\
\hline Second degree & & & $1.25^{* *}$ \\
\hline n.a. & & & $3.37 * * *$ \\
\hline \multicolumn{4}{|l|}{ Age of first second child in months (slope) } \\
\hline $0-20$ & $0.016^{*}$ & $0.016^{*}$ & $0.018^{* *}$ \\
\hline $20-72$ & $-0.011 * * *$ & $-0.011 * * *$ & $-0.009 * * *$ \\
\hline $72+$ & $-0.009 * * *$ & $-0.009 * * *$ & $-0.009 * * *$ \\
\hline Constant & $-5.320 * * *$ & $-5.308 * * *$ & $-5.492 * * *$ \\
\hline Log-likelihood & $-4,255$ & $-4,254$ & $-4,128$ \\
\hline
\end{tabular}

Source: Calculations based on GSOEP, 1984-2004; event: third conception

Note: Significance: $* 10 \%, * * 5 \%, * * * 1 \%$

Next we control for the educational attainment of the spouse. Inserting this covariate to the model further diminishes the birth-risk differentials between the groups under consideration. The educational background of the spouse has a U-shaped influence on third-birth risks. Women who are married to a man without a school-leaving certificate (here, the largest group in the sample are first-generation immigrants) have transition risks that are almost $60 \%$ higher than those of women married to a husband with a first degree or with secondary education $(+25 \%)$. 
Table 7 Factors influencing the transition to a third child: country of origin—relative risks

\begin{tabular}{lc}
\hline Variable & Model 2.4 \\
\hline West German & 1 \\
Immigrant generation and country of origin & $1.73 * * *$ \\
First generation with second birth in Germany, Turkey & $0.73^{* *}$ \\
First generation with second birth in Germany, SSEE & 1.11 \\
First generation with second birth abroad & $1.42^{*}$ \\
Second generation, Turkey & 0.84 \\
Second generation, SSEE & $-4,113$ \\
Log-likelihood & \\
\hline
\end{tabular}

Note: Significance: $* 10 \%, * * 5 \%, * * * 1 \%$; controlled for age of the second child age at second birth, birth cohort, school education of the woman; school education of spouse

SSEE (Southern and Southeastern Europe): Yugoslavia, Greece, Italy, Spain

\subsubsection{Model 2.4}

Finally, in order to test the socialization hypothesis, we draw a comparison within the immigrant generation groups by country background. Again due to the sample size, the women of Yugoslavian, Greek, Italian, and Spanish descent are grouped into a single category (SSEE-Southern and Southeastern Europe). Model 2.4 (Table 7) detects significant differences between Turkish women and women from SSEE countries. The highest transition rates to a third child are estimated for firstgeneration immigrants from Turkey, whose risk is $73 \%$ higher than that of West Germans. In contrast to the second-child behavior, second-generation migrants of Turkish descent have significantly higher transition rates as well $(+42 \%)$. Meanwhile, the risk of having a third child is significantly lower for first-generation immigrants from SSEE countries ( $-27 \%$ compared to West Germans), whereas the difference between the second SSEE generation and West Germans is not significant.

\section{Discussion}

Neither of the analyses finds any evidence for a disruptive effect of migration on fertility. On the contrary, first-generation immigrants have higher transition rates to each of the two births than do women of the second immigrant generation and West Germans. In fact, we find that women who immigrated with a child have higher parity-progression rates than first-generation immigrants who had their first child in West Germany. Even so women in the latter group have higher birth-transition rates than West Germans. Therefore, we conclude that there is neither a short- nor a midterm disruption effect of the migration as such on fertility.

There is only a single exception, namely that this generalization does not hold for the third birth when the country of origin is taken into account. We find that firstgeneration immigrants from the former Yugoslavia, from Greece, Italy, and Spain 
actually have significantly lower third-birth risks than do West German women (Turks show higher risks than West Germans). Since the lower risks occur only in the third-birth behavior, we do not see this as a disruption effect. Instead, we would place the lower third-birth risks of women from Southern and Southeastern European countries in the context of socialization and see these differences as reflections of the fertility changes in the respective countries of origin along with adaptive behavior at destination.

In contrast, the analyses of the second and third births show that the hypothesis of the interrelation of events is not only true for the 'three-pack' of migration, first marriage, and first child of first-generation immigrants (as shown in Milewski 2007). Our study reveals that women moving with one or two children also exhibit higher subsequent birth risks than do women who immigrated before they had any children, and also higher rates than West Germans. This 'arrival' effect may be related to at least four factors.

First, there is the uncertainty factor. A situation that entails major life changes, such as those associated with international migration, may create feelings of uncertainty for individuals or couples. Children may be seen as reducing uncertainty in such instable situations (Friedman et al. 1994). Second, the move of the woman may serve to complete a migration project of a whole family and end the spatial separation of the husband and wife. Even when the couple does not get married, the process of the formation of the new household or the reunion of the spouses and the family may lead to a 'confirmation' effect. Third, relatively high transition rates after a move could be interpreted as catch-up behavior for births that were postponed in the phase preceding the move. This remains a speculation, however, for it cannot be demonstrated with this data as the dataset contains no information about the women who remain in the respective countries of origin. (Given adequate data one would look for reduced fertility after the separation of the spouses.) Fourth, women who moved after the first or second child had been born were relatively young when they became mothers. Younger women may be more prone to have a larger family than women who become mothers at later ages would have, as is traditional in the respective countries of origin, and they may therefore have intended to have more children. Again, this is a speculation that cannot be checked with our data.

We may, however, consider the impact that policies may play in directly or indirectly influencing fertility behavior in a migration context. The first (West) German law is the law relating to the childcare benefit, which is generally paid for 2 years: women from EU countries receive the benefit even if they give birth to and raise the child in their country of origin, provided that they worked in Germany before the birth. This is in contrast to rules that apply to families from non-EU countries, who, since 1986, only receive child benefits for children born and raised in Germany (Schwarz 1996). Hence, women from Turkey and the former Yugoslavia may postpone childbearing in anticipation of the move. The work permit is the second law that is relevant in the context of the fertility behavior of immigrants. Since the end of the recruitment policies, foreigners migrating to Germany have not been allowed to work immediately after the move. People coming from EU-member states are not affected by this rule, in contrast to the family members of persons from non-EU countries who move to Germany for 
reasons of family reunion. Since 1974, persons immigrating for reasons of family reunion have not received a work permit during the initial years following the immigration (Münscher 1979; Angenendt 2002). Therefore, particularly the first years following the move may be seen as a time that offers few opportunities likely to compete with childbearing and childraising; in other words, immigrants may view this interval as a good time to have children (c.f. Milewski 2007).

Moreover, the study supplies evidence supporting the hypothesis of adaptive behavior of first-generation immigrants. Women who had their first child in Germany have lower risks of having a subsequent birth than first-generation immigrants who arrive only after having one or two births. Our analyses confirm the hypothesis of compositional differences between the immigrant generations and West Germans as well. Fertility differentials are diminished or disappear when we control for women's socio-demographic factors. This applies both to first- and second-generation immigrants. The crucial variable is the educational attainment of the women.

Fertility differentials that remain after controlling for duration factors and compositional differences between the groups under investigation are usually attributed to the impact of socialization. This study finds evidence for the socialization hypothesis. The first aspect of the socialization hypothesis is the comparison between the immigrant generations: second-generation migrants have birth-transition risks that resemble more closely those of West Germans than those of first-generation immigrants. The second aspect, differential fertility due to differences in the countries of origin, has also been shown to be true in our study. Large differences in third-birth risks are found for first-generation immigrants by country background, with Turks having much higher birth risks than West Germans, and women from the former Yugoslavia, Greece, Italy, and Spain having even lower transition rates than German women.

Fertility differences between women of Turkish descent and women of SSEE background continue in the second generation, with Turks having higher fertility. Since one of the working hypotheses of our study is that the low-fertility context in West Germany tends to influence fertility behavior to the extent that women of the second immigrant generation start to exhibit fertility behaviors similar to those of West Germans, the question arises as to why the 'Turkish case' is different. Our study does not suggest that Turks in Germany follow a path that leads to 'segmented assimilation' (e.g., Portes and Zhou 1993). According to the segmented-assimilation theory, the socio-demographic development of a minority group would follow a path that is distinct from the pattern of other groups. Since social capital and intergenerational mobility are not the topic of the study presented here, no conclusion can be drawn on this subject. The sample does, however, give the impression that there is a trend towards higher educational attainment among the second generation than among the first generation. Although the socio-demographic structure of all immigrant groups may still be characterized by the former 'guest-worker' milieu, there appears to be a development towards a differentiation within each country group. This has also been pointed out by several authors (e.g., Bade 1994; Fritzsche 2000). 
Even though the segmented-assimilation theory cannot be supported for the West German context, it seems that there is a trend towards the development of a sub-culture: family norms, values, and behavior are influenced by the social context. Fertility behavior can, therefore, supply a hint as to whether a social context exists that provides its members with values that are different from others. In the 'Turkish case,' it seems that there continues to be a stronger orientation towards marriage and a higher number of children than is the case among West Germans and women from SSEE countries. What are the specific differentiating factors? First, there is the strong association between leaving the parental home and marriage in the Turkish community. Young women often mention marriage as the only way they may leave the parental home (Straßburger 2003). Second, marriage and childbearing are themselves connected in that not only is nonmarital childbearing not tolerated, but childless marriages are also not well-regarded (e.g. Yavuz 2008). Third, a high share of transnational marriages, i.e., with persons from Turkey, reinforces 'traditional' Turkish values that are often seen as pure, and in opposition to German majority values and behaviors (Straßburger 2003). Obviously, there is a Turkish family culture which is subject to norms and ideals, and which also transmits these values. Religious affiliation does not appear to have an impact on fertility behavior, but culture clearly does.

For the purposes of future analysis, it may be worthwhile to further differentiate the second immigrant generation; for example, to distinguish persons who moved with their parents from persons who were born at destination. Immigrant children who moved during childhood may feel more attached to their country of origin and be more likely to maintain social networks there than persons of the second generation who were born in West Germany only after their parents' move. Therefore, the influence of the culture of the country of origin and of social networks, both in the country of origin and in Germany, may be different for the two groups of the second generation, and may lead to differences in family formation and fertility as well.

Finally, we would like to point out that fertility behavior must be seen in a wider context. Our analysis is able to show fertility patterns of immigrants in West Germany and influencing factors, but it cannot explain in full why these patterns and differences between the sub-groups occur. In order to fully understand the fertility behavior of immigrants, one would also want to consider union formation, educational participation, and gender roles within a sub-cultural setting. Attention to gender roles is especially important in the context of family policies and women's policies. Immigrant sub-groups within a population may be different from, or show more variations than, the majority population; examples are prominent in family structure, social inequality, family relations, and division of labor between women and men. Since welfare states are based on certain assumptions about the relative homogeneity of their populations, it may be rewarding and necessary to investigate the effects of policies on sub-groups who differ from the majority population.

Acknowledgments The author thanks Hill Kulu and Jan M. Hoem for helpful discussions of earlier versions of the paper and advice. Comments and suggestions from the members of the former research Laboratory of Contemporary European Fertility and Family Dynamics at the Max Planck Institute for Demographic Research, Rostock, where this research project was carried out, are gratefully acknowledged, as are the constructive comments of two anonymous reviewers. 


\section{References}

Abbasi-Shavazi, M. J., \& McDonald, P. (2000). Fertility and multiculturalism: Immigrant fertility in Australia, 1977-1991. International Migration Review, 34(1), 215-242.

Abbasi-Shavazi, M. J., \& McDonald, P. (2002). A comparison of fertility patterns of European immigrants in Australia with those in the countries of origin. Genus, 58, 53-76.

Alders, M. (2000). Cohort fertility of migrant women in the Netherlands. Developments in fertility of women born in Turkey, Morocco, Suriname, and the Netherlands Antilles and Aruba. Paper for the BSPS-NVD-URU conference, 31 August-1 Sept 2000. Utrecht, Statistics Netherlands.

Andersson, G. (2004). Childbearing after migration: Fertility patterns of foreign-born women in Sweden. International Migration Review, 38(2), 747-775.

Andersson, G. \& Scott, K. (2007). Childbearing dynamics of couples in a universalistic welfare state: the role of labor-market status, country of origin, and gender. Demographic Research, 17(30), 897-938. www.demographic-research.org/volumes/vol17/30/.

Angenendt, S. (2002). Einwanderungspolitik und Einwanderungsgesetzgebung in Deutschland 20002001. In K. J. Bade \& R. Münz (Hgs.), Migrationsreport 2002. Fakten-Analysen-Perspektiven (pp. 31-59). Frankfurt: Campus Verlag.

Bach, R. L. (1981). Migration and fertility in Malaysia: A tale of two hypotheses. International Migration Review, 15(3), 502-521.

Bade, K. J. (1994). Ausländer, Aussiedler, Asyl in der Bundesrepublik Deutschland, 3. Aufl. Hannover: Niedersächsische Landeszentrale für politische Bildung.

Bean, F. D., \& Marcum, J. P. (1978). Differential fertility and the minority group status hypothesis: An assessment and review. In Conference proceedings on the demography of racial and ethnic groups. Based on papers presented at a Conference held in Austin (pp. 189-211). New York: Academic Press.

Bean, F. D., \& Swicegood, G. (1985). Mexican American fertility patterns. Austin: University of Texas Press.

Bean, F. D., \& Tienda, M. (1990). The Hispanic population of the United States. In National committee for research on the 1980 Census. The Population of the United States in the 1980s. New York: Russel Sage Foundation.

Bender, S., \& Seifert, W. (2000). Zur beruflichen und sozialen Integration der in Deutschland lebenden Ausländer. In R. Alba, P. Schmidt, \& M. Wasmer (Hgs.), Deutsche und Ausländer-Freunde, Fremde oder Feinde? Empirische Befunde und theoretische Erklärungen (pp. 55-91). Opladen: Westdeutscher Verlag.

Blossfeld, H.-P., \& Rohwer, G. (1995). Techniques of event history modelling. New approaches to causal analyses. Mahwah: Lawrence Earlbaum Associates.

BMFSFJ-Bundesministerium für Familie, Senioren, Frauen und Jugend (Hg). (2000). Familien ausländischer Herkunft in Deutschland. Leistungen, Belastungen, Herausforderungen. Sechster Familienbericht. Berlin: BMFSFJ.

Carlson, E. D. (1985). The impact of international migration upon timing of marriage and childbearing. Demography, 22(1), 61-72.

Constant, A., \& Massey, D. S. (2005). Labor market segmentation and the earnings of German guestworkers. Population Research and Policy Review, 24, 489-512.

Delgado Perez, M., \& M. Livi-Bacci. (1992). Fertility in Italy and Spain: The lowest in the world. Family Planning Perspectives, 24(4), 162-167, 171

Destatis. (2005). Statistisches Bundesamt. Gebiet und Bevölkerung-Ausländische Bevölkerung. www.statistik-portal.de/Statistik-Portal/de_jb01_jahrtab2.asp.

DIW-Deutsches Institut für Wirtschaftsforschung. (2006). http://panel.gsoep.de/soepinfo2005/.

Farber, S. C., \& Lee, B. S. (1984). Fertility adaptation of rural-to-urban migrant women: A method of estimation applied to Korean women. Demography, 21, 339-345.

Fassmann, H. (1997). Is the Austrian labour market ethnically segmented? European Journal of Population, 13, 17-32.

Ford, K. (1990). Duration of Residence in the United States and the Fertility of U.S. Immigrants. International Migration Review, 24(1), 34-68.

Frank, R., \& Heuveline, P. (2005). A cross-over in Mexican and Mexican-American fertility rates: Evidence and explanations for an emerging paradox. Demographic Research, 12(4), 77-104. www.demographic-research.org/Volumes/Vol12/4/. 
Friedman, D., Hechter, M., \& Kanazawa, S. (1994). The theory of the value of children. Demography, 31, 375-401.

Fritzsche, Y. (2000). Die quantitative Studie: Stichprobenstruktur und Feldarbeit. In A. Fischer, Y. Fritzsche, W. Fuchs-Heinritz, \& R. Münchmeier (Hgs.), 13. Shell Jugendstudie, Bd. 1/Quantitative Studie (pp. 349-378). Opladen: Leske and Budrich.

Garssen, J., \& Nicolaas, H. (2008). Fertility of Turkish and Moroccan women in the Netherlands: Adjustment to native level within one generation. Demographic Research, 19(33), 1249-1280. www.demographic-research.org/Volumes/Vol19/33/.

Goldscheider, C., \& Uhlenberg, P. R. (1969). Minority group status and fertility. The American Journal of Sociology, 74(4), 361-372.

Goldstein, A., White, M., \& Goldstein, S. (1997). Migration, fertility, and state policy in Hubei province, China. Demography, 34(4), 481-491.

Gordon, M. (1964). Assimilation in American life. Oxford: Oxford University Press.

Haisken-DeNew, J. P., \& J. R. Frick. (2003). (Eds.), Desktop companion to the German Socio-Economic Panel Study (SOEP). Version 7.0. Updated to Wave 19(S). Berlin: DIW.

Hancioglu, A., \& Ergöcmen, B. A. (2004). Women's characteristics and status. In: Hacettepe University Institute of Population Studies. Turkey Demographic and Health Survey, 2003 (pp. 33-44). Ankara: HUIPS, Ministry of Health General Directorate of Mother and Child Health and Family Planning, State Planning Organization and European Union.

Hennig, S., \& Kohlmann, A. (1999). Determing fertility behaviour: a comparison of foreign-born in the U.S. and Germany. In R. Münz \& W. Seifert (Eds.), Inclusion or exclusion of immigrants: Europe and the U.S. at the crossroads (Demographie aktuell 14, pp. 43-55). Berlin: Humboldt-Universität.

Hervitz, H. M. (1985). Selectivity, adaptation, or disruption? A comparison of alternative hypotheses on the effects of migration on fertility: The case of Brazil. International Migration Review, 19(2), 293-317.

Hiday, V. A. (1978). Migration, urbanization, and fertility in the Philippines. International Migration Review, 12(3), 370-385.

Hoem, J. M. (1987). Statistical analysis of a multiplicative model and its application to the standardization of vital rates: A review. International Statistical Review, 55(2), 119-152.

Hoem, J. M. (1993). Classical demographic methods of analysis and modern event-history techniques. In IUSSP, 22nd international population conference, Montreal (Vol. 3, pp. 281-291).

Hoem, J. M., \& M. Kreyenfeld (2006). Anticipatory analysis and its alternatives in life-course research: Part 1: Education and first childbearing. Demographic Research, 15(16), 461-484. www.demographicresearch.org/volumes/vol15/16/.

Hwang, S.-S., \& Saenz, R. (1997). Fertility of Chinese immigrants in the U.S.: Testing a fertility emancipation hypothesis. Journal of Marriage and the Family, 59(1), 50-61.

Iutaka, S., Bock, E. W., \& Varnes, W. G. (1971). Factors affecting fertility of natives and migrants in urban Brazil. International Migration Review, 25(1), 55-62.

Kahn, J. R. (1988). Immigrant selectivity and fertility Adaptation in the United States. Social Forces, 67(1), 108-128.

Kahn, J. R. (1994). Immigrant and native fertility during the 1980s: Adaptation and expectations for the future. International Migration Review, 28(3), 501-519.

Kane, T. T. (1986). The fertility and assimilation of guestworker populations in the Federal Republic of Germany: 1961-1981. Zeitschrift für Bevölkerungswissenschaft, 12(1), 99-131.

Khoo, S.-E., McDonald, P., Giorgas, D., \& Birrell, B. (2002). Second ceneration Australians. Canberra: Department of Immigration and Multicultural and Indigenous Affairs, Australian Centre for Population Research.

Konietzka, D., \& Seibert, H. (2003). Deutsche und Ausländer an der „zweiten Schwelle. Eine vergleichende Analyse der Berufseinstiegskohorten 1976-1995 in Westdeutschland. Zeitschrift für Pädagogik, 49(4), 567-590.

Kravdal, Ø. (2007). Effects of current education on second- and third-birth rates among Norwegian women and men born in 1964: Substantive interpretations and methodological issues. Demographic Research, 17(9), 211-246. demographic-research.org/Volumes/Vol17/9/.

Kreyenfeld, M. (2001): Employment and fertility. East Germany in the 1990s [doctoral thesis]. Rostock: University of Rostock

Kreyenfeld, M. (2002). Time squeeze, partner effect or self-selection?: An investigation into the positive effect of women's education on second birth risks in West Germany. Demographic Research, 7(2), 15-48. www.demographic-research.org/Volumes/Vol7/2/. 
Kulu, H. (2005). Migration and fertility: Competing hypotheses re-examined. European Journal of Population, 21, 51-87.

Kulu, H. (2006). Fertility of internal migrants: Comparison between Austria and Poland. Population, Space and Place, 12, 147-170.

Kulu, H., \& Milewski, N. (2007). Family change and migration in the life course: An introduction. Demographic Research, 17(19), 567-590. www.demographic-research.org/Volumes/Vol17/19/.

Landale, N. S., \& Hauan, S. M. (1996). Migration and premarital childbearing among Puerto Rican women. Demography, 33(4), 429-442.

Lindstrom, D. P. (2003). Rural-urban migration and reproductive behavior in Guatemala. Population Research and Policy Review, 22, 351-372.

Macisco, J. J., Jr., Bouvier, L. F., \& Renzi, M. J. (1969). Migration Status, education and fertility in Puerto Rico, 1960. The Milbank Memorial Fund Quarterly, 47(2), 167-186.

Macisco, J. J., Bouvier, L. F., \& Weller, R. H. (1970). The effect of labor force participation on the relation between migration status and fertility in San Juan, Puerto Rico. The Milbank Memorial Fund Quarterly, 48(1), 51-70.

Massey, D. S. (1981). Dimensions of the new immigration to the United States and the prospects for assimilation. Annual Review of Sociology, 7, 57-85.

Mayer, J., \& Riphahn, R. T. (2000). Fertility assimilation if immigrants: Evidence from count data models. Journal of Population Economics, 13, 241-261.

Milewski, N. (2007). First child of immigrant workers and their descendants in West Germany: Interrelation of events, disruption, or adaptation? Demographic Research, 17(29), 859-896. www. demographic-research.org/Volumes/Vol17/29/.

Mulder, C. H. (1993). Migration dynamics: a life course approach [Doctoral Thesis]. Amsterdam: Thesis Publishers.

Mulder, C. H., \& Wagner, M. (1993). Migration and marriage in the life course: A method for studying synchronized events. European Journal of Population, 9, 55-76.

Münscher, A. (1979). Ausländische Familien in der Bundesrepublik Deutschland-Familiennachzug und generatives Verhalten. München: DJI Verlag.

Münz, R., \& Ulrich, R. (2000). Die ethnische und demographische Struktur von Ausländern und Zuwanderern in Deutschland. In R. Alba, P. Schmidt, \& M. Wasmer (Hgs.), Deutsche und Ausländer: Freunde, Fremde oder Feinde? Empirische Befunde und theoretische Erklärungen (pp. 11-54). Wiesbaden: Westdeutscher Verlag.

Nauck, B. (1987). Individuelle und kontextuelle Faktoren der Kinderzahl in türkischen Migrantenfamilien. Zeitschrift für Bevölkerungswissenschaft, 13(3), 319-344.

Nauck, B. (2007). Immigrant families in Germany. Family change between situational adaptation, acculturation, segregation and remigration. Zeitschrift für Familienforschung, 19(1), 34-54.

Nedoluzhko, L., \& Andersson, G. (2007). Migration and first-time parenthood: Evidence from Kyrgyzstan. Demographic Research, 17(25), 741-774. www.demographic-research.org/Volumes/Vol17/25/.

$\mathrm{Ng}$, E., \& Nault, F. (1997). Fertility among recent immigrant women to Canada, 1991: An examination of the disruption hypothesis. International Migration Review, 35(4), 559-580.

Portes, A., \& Zhou, M. (1993). The new second generation: Segmented assimilation and its variants. Annals of the American Academy of Political and Social Science, 530, 74-96 (Interminority Affairs in the U.S.: Pluralism at the Crossroads).

Poston, D. L., Jr., Chang, C.-F., \& Dan, H. (2006). Fertility differences between the majority and minority nationality groups in China. Population Research and Policy Review, 25, 67-101.

Ram, B., \& George, M. V. (1990). Immigrant fertility patterns in Canada, 1961-1986. International Migration, 28(4), 413-426.

Rindfuss, R. R. (1976). Fertility and migration: The case of Puerto Rico. International Migration Review, 10(2), 191-203.

Roberts, R. E., \& Lee, E. S. (1974). Minority group status and fertility revisited. The American Journal of Sociology, 80(2), 503-523.

Roloff, J. (1997). Die ausländische und deutsche Bevölkerung in der Bundesrepublik Deutschland-ein bevölkerungsstatistischer Vergleich. Zeitschrift für Bevölkerungswissenschaft, 22(1), 73-98.

Rudolph, H. (2002). Dynamics of Immigration in a Nonimmigrant Country: Germany. In R. Fassmann \& H. Münz (Eds.), European migration in the late twentieth century. Historical patterns, actual trends, social implications (2nd ed., pp. 113-126). Laxenburg: IIASA.

Rumbaut, R. G. (2004). Ages, life stages, and generational cohorts: decomposing the immigrant first and second generations in the United States. International Migration Review, 38(3), 1160-1205. 
Sabagh, G., \& Yim, S. B. (1980). The relationship between migration and fertility in an historical context: The case of Morocco in the 1960s. International Migration Review, 14(4), 525-538.

Schoenmaeckers, R. C., Lodewijckx, E., \& Gadeyne, S. (1998). Vruchtbaarheid bij Turkse en Marokkaanse vrouwen in Belgie: Resultaten van de volkstellingen. Bevolking en Gezin, 27(3), 127-154.

Schoorl, J. J. (1990). Fertility adaptation of Turkish and Moroccan women in the Netherlands. International Migration, 28, 477-495.

Schoorl, J. J. (1995). Fertility trends of immigrant populations. In S. Voets, J. Schoorl, \& B. de Bruijn (Eds.), The demographic consequences of international migration. Proceedings of the symposium, NIAS, Wassenaar, 27-29 September 1990 (pp. 97-121). The Hague: NIDI.

Schwarz, K. (1996). Die Kinderzahl der Ausländer und ihre Bedeutung für die Bevölkerungsentwicklung in den alten Bundesländern. Zeitschrift für Bevölkerungswissenschaft, 21(1), 57-67.

Seifert, W. (1997). Occupational and economic mobility and social integration of mediterranean migrants in Germany. European Journal of Population, 13, 1-16.

Shorter, F. C., \& Macura, M. (1982). Trends in fertility and mortality in Turkey, 1935-1975. Committee on population and demography report No. 8. Washington, DC: Committee on Population and Demography.

Singley, S. G., \& Landale, N. S. (1998). Incorporating origin and process in migration-fertility frameworks: The case of Puerto Rican Women. Social Forces, 76(4), 1437-1464.

Sly, D. F. (1970). Minority-group status and fertility: An extension of Goldscheider and Uhlenberg. The American Journal of Sociology, 76(3), 443-459.

Sobotka, T. (2008). Overview chapter 7: The rising importance of migrants for childbearing in Europe. Demographic Research, 19(9), 225-248. www.demographic-research.org/Volumes/Vol19/9/.

Stephen, E. H., \& Bean, F. D. (1992). Assimilation, disruption and the fertility of Mexican-origin women in the United States. International Migration Review, 26(1), 67-88.

Straßburger, G. (2003). Heiratsverhalten und Partnerwahl im Einwanderungskontext. Eheschließungen der zweiten Migrantengeneration türkischer Herkunft [Doctoral Thesis]. Würzburg: Ergon Verlag.

Vaskovics, L. A. (1987). Geburtenentwicklung, Fruchtbarkeit und demographische Entwicklung bei Gastarbeitern. In H. Reimann \& H. Reimann (Hgs.), Gastarbeiter (Vol. 2, pp. 222-242). Aufl. Opladen: Leske and Budrich

Wagner, M. (1990). Education and migration. In K. U. Mayer \& N. B. Tuma (Eds.), Event history analysis in life course research (pp. 129-145). Madison: The University of Wisconsin Press.

Yavuz, S. (2008). Fertility decline in turkey from the 1980s onwards: Patterns by main language groups [Doctoral Thesis]. Ankara: HUIPS.

Zarate, A., \& Unger de Zarate, A. (1975). On the reconciliation of research findings of migrantnonmigrant fertility differentials in urban areas. International Migration Review, 9, 115-156. 